\title{
Horizontale transities als loopbaanperspectief
}

\author{
Joop Schippers ${ }^{*}$
}

Terwijl weer een sprankje hoop gloort op een piepklein beetje groei van de Nederlandse economie, zien we toenemende consensus over het feit dat het kwakkelen geblazen blijft met de werkgelegenheid. Het UWV gaf eerder aan dat een substantiële reductie van de werkloosheid op zijn vroegst ruim in de tweede helft van het lopende decennium te verwachten valt, terwijl een studie van ABN Amro onlangs forse vraagtekens zette bij de eerdere voorspellingen van toenemende krapte op de Nederlandse arbeidsmarkt uit hoofde van de vergrijzing en ontgroening. Ondertussen houdt de stroom van berichten in de media over reorganisaties en omvangrijke collectieve ontslagen aan. Dat geldt - zij het met een minder hoge frequentie - eveneens voor berichten over allerhande technologische innovaties. Denk aan robots in de zorg of de mogelijkheid auto's zonder chauffeur te laten rijden. Het zal nog wel even duren voor het echt zover is, maar dat zeiden we ooit ook over het verdwijnen van lokettisten of de kassajuffrouw. Onmiskenbaar is echter dat de introductie van arbeidsbesparende technologie voortschrijdt. Dat was zo voor de economische crisis, dat is tijdens de crisis doorgegaan en zal ook nu er sprake lijkt van enig herstel, niet stoppen.

Daarmee dreigt gedurende het komende decennium stagnatie op de arbeidsmarkt het parool te worden. Dat heeft enerzijds te maken met het aantal banen en de omvang van de beroepsbevolking. Anderzijds speelt daarbij een rol dat er (op macroniveau) niet langer een natuurlijke 'fit' bestaat tussen de (leeftijds)opbouw van die beroepsbevolking en de opbouw van de werkgelegenheid. Een halve eeuw geleden zag de beroepsbevolking er nog min of meer uit als een piramide: veel jongere werknemers vormden de basis en naarmate je hoger in de piramide kwam (en dus in de hogere leeftijdsklassen), nam het aantal leden per cohort af. Dat paste prettig bij de opbouw van de werkgelegenheid, die ook een piramidale structuur had: veel werkvolk aan de basis en steeds kleinere aantallen mensen naarmate je hoger in de hiërarchie kwam. Hoewel veel organisaties een inherente tendens kennen om te verworden tot een Mexicaans leger (steeds meer generaals en amper nog soldaten), zorgen frequente reorganisaties en afslankoperaties ervoor dat die piramidale werkgelegenheidsstructuur grosso modo gehandhaafd blijft. Dat kunnen we van de beroepsbevolking niet zeggen. Daarbinnen is het zwaartepunt uitdrukkelijk verschoven in de richting van de vijftigplussers, waardoor de beroepsbevolking inmiddels meer op een urn lijkt.

De consequentie van die verminderde 'fit' tussen beroepsbevolking en werkgelegenheidsstructuur is dat steeds meer werknemers - en zeker zij die behoren tot de jongere generaties - zullen oplopen tegen het feit dat de hogere echelons binnen organisaties vol zitten. Niet alleen nu, maar vrijwel permanent. Doorstroom

* Joop Schippers is als hoogleraar Arbeidseconomie verbonden aan de Universiteit Utrecht. 
lijkt eerder uitzondering dan regel te worden en baanloze groei en voortgaande 'rationalisering van productieprocessen' beperken die mogelijkheden nog verder. Steeds meer zullen werkenden er dus aan moeten wennen dat een loopbaan zich niet langer automatisch kenmerkt door opwaartse mobiliteit. Wie zijn werkzame leven een beetje leuk wil houden, zal zich in toenemende mate moeten overgeven aan horizontale mobiliteit. Om in die termen over een loopbaan te denken is echter nog geen gemeengoed. En het vergt van de werknemer voldoende 'transitievaardigheden'.

Bij transitievaardigheden gaat het over meer dan functiespecifieke kennis en vaardigheden. Natuurlijk, die zijn ook nodig om een ander takenpakket met succes aan te vatten. Maar het gaat ook om een 'mindset': de bereidheid om een nieuwe taak en eventueel een nieuwe omgeving met enthousiasme tegemoet te treden, niet te blijven treuren om het verlies van oude collega's of die mooie werkplek waar je zo aan gehecht was. In principe houdt elke transitie - opwaarts of horizontaal - het verlies van zekerheden in. Bij promoties, die de traditionele loopbaan bepaalden, was er in elk geval een stijging in salaris en status als pleister op de wonde van dit verlies. Bij horizontale transities zal die compensatie op een andere manier vorm moeten krijgen. Daarbij hebben ook de organisatie en de leidinggevende een belangrijke rol te spelen.

Ook onder leidinggevenden zal de gedachte moeten groeien dat de loopbaan van een werknemer meer behelst dan de simpele keuze 'omhoog' of 'blijven zitten' (dan wel - in sommige organisaties: 'up or out'). Het meedenken over en formuleren van horizontale alternatieven vergt de nodige creativiteit. Dat geldt als het alternatieven betreft binnen de organisatie, maar al helemaal als het 'externe' alternatieven betreft: bij een ander bedrijf of wellicht zelfs als zelfstandige. Je moet als leidinggevende voldoende inzicht hebben in wat een werknemer kan (en niet kan), wat hem of haar drijft en beweegt, en wat voor de werknemer het alternatief aantrekkelijk zou kunnen maken (en het onvermijdelijke verlies bij het vertrek uit de oude functie zou kunnen compenseren). Dat kan niet zonder goede dossiervorming, regelmatige functioneringsgesprekken en echte betrokkenheid. Binnen sommige organisaties is dat allemaal op orde, maar elders valt nog een wereld te winnen. De optie van horizontale carrièrestappen - in sommige opzichten een invulling van het concept functionele flexibiliteit, dat in Nederland nooit echt goed van de grond is gekomen - zal niet alleen in functioneringsgesprekken aan de orde moeten komen, maar ook zijn neerslag moeten vinden in de mogelijkheid van stages, meeloopdagen en kennismakingsbezoeken. Werknemers moeten immers ook de kans krijgen zich te oriënteren op alternatieven.

Veelal zijn hoger opgeleiden beter geëquipeerd voor het maken van een overstap dan lager opgeleiden. De transitievaardigheden die eerder aan de orde kwamen, appelleren in hoge mate aan algemeen menselijk kapitaal, terwijl lager opgeleiden (tot en met het mbo toe) vooral voor één specifiek beroep of één specifieke richting op de arbeidsmarkt worden opgeleid en dus vooral over specifiek menselijk kapitaal beschikken. Juist zij zijn - ook in het licht van de eerder gememoreerde technologische innovaties - in de toekomst mogelijk vaker op horizontale mobili- 
teit aangewezen. Dat plaatst niet alleen organisaties, maar ook het onderwijs voor een uitdaging. Vaak is het al een hele klus jongeren de kennis en basisbeginselen van één vak bij te brengen. Het vooruitzicht ze ook nog de transitievaardigheden te moeten meegeven die hen in staat stellen gedurende de loopbaan een horizontale carrièrestap te maken, doet de verantwoordelijken mogelijk naar adem happen. Maar als we echt werk maken van een leven lang leren, hoeft het ook niet allemaal in één keer en binnen de context van het initieel onderwijs. Juist het post-initieel onderwijs lijkt - aansluitend bij de ervaring die werknemers geleidelijk aan opdoen - bij uitstek geschikt om werknemers te helpen de zo noodzakelijke transitievaardigheden (verder) te ontwikkelen.

Maar dan moeten we daar wel eens echt werk van gaan maken. Anders zitten we dadelijk niet alleen met een verloren generatie jongeren en 55-plussers, maar ook met een vastgelopen generatie dertigers en veertigers. 